\title{
Tampão Peridural com Dextran 40 na Profilaxia da Cefaléia Pós-Punção Acidental da Duramáter em Paciente HIV Positivo. Relato de Caso *
}

\author{
Epidural Patch with Dextran 40 to Prevent Postdural Puncture \\ Headache in an HIV Patient. Case Report
}

Marcos Guilherme Cunha Cruvinel, TSA ${ }^{1}$, Paulo Roberto Vieira Barbosa ${ }^{2}$, Vera Coelho Teixeira, TSA ${ }^{3}$, Carlos Henrique Viana de Castro, TSA ${ }^{4}$

\section{RESUMO}

Cruvinel MGC, Barbosa PRV, Teixeira VC, Castro CHV - Tampão Peridural com Dextran 40 na Profilaxia da Cefaléia Pós-Punção Acidental da Duramáter em Paciente HIV Positivo. Relato de Caso

Justificativa e Objetivos - A cefaléia pós-punção de duramáter é uma complicação bem conhecida das anestesias subaracnóideas e peridurais, sendo o tampão sangüíneo considerado o tratamento mais eficaz, até o momento. Este é um procedimento invasivo e sujeito a complicações graves. Seu uso em certos pacientes, como portadores de HIV ou leucemias, é motivo de debate. Várias alternativas têm sido relatadas. O objetivo deste artigo é apresentar um caso do uso do tampão peridural com dextran 40 na profilaxia da cefaléia pós-punção de duramáter em paciente portador do vírus da imunodeficiência humana (HIV), com história de cefaléia em anestesia subaracnóidea anterior.

Relato do Caso - Paciente masculino, 31 anos, $70 \mathrm{~kg}$, estado físico ASA II, portador de HIV, para tratamento de condilomatose anal recidivada, com relato de cefaléia intensa e limitante durante duas semanas após anestesia subaracnóidea (agulha Quincke 25G). Durante tentativa de anestesia peridural com agulha de Tuohy $18 \mathrm{G} \mathrm{em} L_{3}-L_{4}$, houve perfuração acidental da duramáter. Foram injetados, por duas vezes, $20 \mathrm{ml}$ de dextran 40 a $10 \%$ por cateter peridural; a primeira, 150 minutos após a administração dos anestésicos e a segunda na manhã seguinte à cirurgia. O paciente evoluiu assintomático e recebeu alta no dia seguinte à sua internação.

Conclusões - O uso do tampão com soluções colóides como o dextran 40 não está bem estabelecido, porém existem alguns relatos do seu uso com sucesso e entendemos que seu potencial deva ser melhor explorado.

\footnotetext{
* Recebido do (Received from) Departamento de Anestesiologia do Hospital Felício Rocho, Belo Horizonte, MG

1. Especialista em Clínica Médica; Co-responsável pelo CET/SBA do Hospital Felício Rocho; Anestesiologista do Hospital Mater Dei

2. Anestesiologista do Hospital Felício Rocho

3. Especialista em Terapia Intensiva e Clínica Médica; Responsável pelo CET/SBA do Hospital Felício Rocho

4. Especialista em Terapia Intensiva e Clínica Médica; Co-responsável pelo CET/SBA do Hospital Felício Rocho; Anestesiologista do Hospital Mater Dei
}

Apresentado (Submitted) em 14 de janeiro de 2002

Aceito (Accepted) para publicação em 05 de abril de 2002

Correspondência para (Mail to):

Dr. Carlos Henrique Viana de Castro

Rua Simão Irffi, 86/301

Bairro Coração de Jesus

30380-270 Belo Horizonte, MG

(C) Sociedade Brasileira de Anestesiologia, 2002
UNITERMOS: COMPLICAÇÕES: cefaléia; TÉCNICAS ANESTÉSICAS, Regional: peridural, subaracnóidea

\section{SUMMARY}

Cruvinel MGC, Barbosa PRV, Teixeira VC, Castro CHV - Epidural Patch with Dextran 40 to Prevent Postdural Puncture Headache in an HIV Patient. Case Report

Background and Objectives - Postdural puncture headache is a well-known complication of spinal and epidural anesthesia and, so far, its most effective treatment is the epidural blood patch. Nevertheless this is an invasive procedure subject to severe complications. Its use in special patient populations (HIV positive patients and leukemias) is controversial. Several alternatives have been reported. This study aimed at showing a case of prophylactic epidural dextran 40 patch in an HIV patient with previous history of headache following spinal anesthesia.

Case Report - Male patient, 31 years old, $70 \mathrm{~kg}$, physical status ASA II, HIV positive, presented for recurrent anal condylomatosis treatment, with a history of severe and limiting headache for two weeks following spinal anesthesia. (25G Quincke needle). During an $L_{3}-L_{4}$ epidural puncture attempt with an $18 \mathrm{G}$ Tuohy needle there was an accidental dural puncture. Twenty milliliters of $10 \%$ dextran 40 were administered twice through an epidural catheter. First, 150 minutes after anesthesia and then in the morning following surgery. Patient had no headache complaint and was discharged on the following day.

Conclusions - The use of a patch with colloid solutions, such as dextran 40, is not well established, but there are some successful reports and it is our understanding that its potential should be further investigated.

KEY WORDS: ANESTHETIC TECHNIQUES, Regional: epidural, spinal block; COMPLICATIONS: headache

\section{INTRODUÇÃO}

cefaléia pós-punção da duramáter (CPPD) pode ocorArer após punção lombar diagnóstica e/ou terapêutica, anestesia subaracnóidea ou punção acidental da duramáter durante punção peridural ${ }^{1,2}$. Ela é tipicamente agravada pelo ortostatismo e aliviada pelo decúbito dorsal horizontal. Estes sintomas característicos devem-se ao vazamento de líquor, levando à diminuição da pressão e/ou volume liquóricos, provocando deslocamento e tração de estruturas intracranianas ${ }^{3,4}$. Também pode contribuir na geração da dor, fenômenos cérebro-vasculares ${ }^{5,6}$. O diagnóstico é essencialmente clínico. Tipicamente, a CPPD tem seu início entre 24 e 48 horas após a punção e evolui para resolução espontânea em alguns dias, porém em alguns casos ela pode ser incapacitante e durar meses ${ }^{3,7,8}$. 
Aincidência de CPPD varia conforme a população estudada. O fator predisponente mais importante é o tamanho da aguIha. Para agulhas Quincke 22G cita-se uma incidência de $15,6 \%$, enquanto que para agulhas Quincke $29 \mathrm{G}$ cita-se uma incidência de $1,4 \%{ }^{9,10}$. Outros fatores como configuração da ponta da agulha e orientação do bisel têm influência ${ }^{11-13}$. O fator, relacionado ao paciente, mais significativo é a idade (os jovens são os mais susceptíveis) ${ }^{11}$. Adificuldade técnica de punção com necessidade de múltiplas punções antes de se obter o sucesso é tida como fator predisponente ${ }^{14}$.

A punção acidental da duramáter durante a tentativa de punção peridural tem incidência que varia entre $0,4 \%$ e $6 \%{ }^{15,16}$. Quando isto ocorre, a incidência de CPPD é alta com relatos de até $86 \%{ }^{17}$.

O objetivo deste relato é mostrar um caso de uso de tampão peridural com dextran 40 na profilaxia da CPPD em paciente portador de HIV, com história de cefaléia em anestesia subaracnóidea anterior.

\section{RELATO DO CASO}

Paciente masculino, 31 anos, 70 kg, estado físico ASAII, portador do vírus da imunodeficiência humana, admitido para tratamento de condilomatose anal recidivada. Relatava cefaléia intensa e limitante durante duas semanas após a primeira cirurgia, que foi realizada sob raquianestesia (agulha Quincke 25G). O tratamento foi realizado com antiinflamatórios, analgésicos, cafeína, hidratação e repouso. Nesta segunda intervenção cirúrgica, optou-se pela realização de

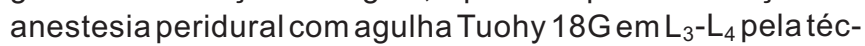
nica da perda da resistência com ar. Houve perfuração acidental da duramáter e nova punção, utilizando-se a mesma técnica em $L_{2}-L_{3}$ que foi realizada com sucesso, procedendo-se o implante de cateter peridural. Foram administradas, em doses incrementais de $40 \mathrm{mg}$, lidocaína a $2 \%$ com epinefrina até uma dose total de $120 \mathrm{mg}$. O procedimento cirúrgico transcorreu sem intercorrências e após 150 minutos da administração do anestésico não havia bloqueio motor ou sensitivo. Foram, então, após consentimento do paciente, administrados pelo cateter, $20 \mathrm{ml}$ de dextran 40 a $10 \%$. O paciente evoluiu assintomático. Após 24 horas da anestesia, foram injetados mais $20 \mathrm{ml}$ de dextran 40 a $10 \%$ e a seguir foi retirado o cateter peridural. O paciente recebeu alta no dia seguinte à cirurgia e permaneceu sem queixa de cefaléia. Durante as primeiras 24 horas após a perfuração acidental da duramáter foram administrados por via oral antiinflamatório (diclofenaco sódico $100 \mathrm{mg}$ ), dipirona ( $2,4 \mathrm{~g}$ ), cafeína (240 mg)e realizada hidratação venosa, com $2400 \mathrm{ml}$ de solução de Ringer com lactato.

\section{DISCUSSÃo}

Várias modalidades de tratamento têm sido propostas para o tratamento da CPPD; no entanto, o tampão sangüíneo peridural é, atualmente, aceito como mais eficaz ${ }^{18-20}$. A injeção de sangue autólogo no espaço peridural foi, inicialmente, su- gerida por Gormley ${ }^{21}$ em 1960 e introduzida, definitivamente, na prática, em 1970 por DiGiovanni e Dunbar ${ }^{22}$. Duas são as teorias para explicar a eficácia do tampão sangüíneo peridural no tratamento da CPPD. Uma delas sugere que a injeção de sangue no espaço peridural cria um coágulo que tampona o orifício da duramáter e previne a perda adicional de líquor $^{23-25}$. A outra diz que o volume de sangue injetado no espaço peridural aumenta a pressão liquórica e reduz a tração cerebral e meníngea, levando ao alívio dos sintomas ${ }^{26,27}$. Ambas as teorias estão corretas ${ }^{28}$. A primeira explica a eficácia a longo prazo do tampão sangüíneo peridural e a segunda, o alívio rápido dos sintomas. O momento ideal de sua administração é motivo de controvérsia, alguns sugerem sua realização após alguns dias de CPPD persistente ${ }^{29}$ e outros preconizam sua realização precoce ${ }^{30,31} \mathrm{e}$, ainda, há quem o indique profilaticamente ${ }^{32,33}$. Também é polêmico o volume ideal a ser injetado, variando de 10 a $20 \mathrm{ml}^{34}$.

Entre as várias outras modalidades de tratamento, citaremos algumas:

- Repouso no leito: promove alívio da cefaléia e conforto ao paciente, sendo uma conduta no tratamento ${ }^{7}$. Não mostrou ser eficiente na prevenção, embora possa atrasar o aparecimento dos sintomas ${ }^{7}$;

- Hormônio Adrenocorticotrópico (ACTH): Kshatri e Foster administraram ACTH (1,5 unidades por kg em 1 a 2 litros de solução de Ringer com lactato) em 20 pacientes com um sucesso de $70 \%{ }^{35}$. Collier foi outro autor que descreveu o uso de um análogo do ACTH no tratamento da CPPD com sucesso ${ }^{36}$. Não há um mecanismo farmacológico aparente para sua eficácia ${ }^{37}$;

- Sumatriptano: é usado para o tratamento da enxaqueca por provocar vasoconstrição cerebral. Seu uso com sucesso na CPPD tem sido relatado por vários autores, tendo a grande vantagem de não ser invasivo ${ }^{38-41}$. A lógica de seu uso baseia-se na teoria da vasodilatação cerebral reflexa como componente fisiopatológico da CPPD ${ }^{42}$. Contudo, não é isento de efeitos adversos e complicações cardiovasculares foram relatadas ${ }^{37}$;

- Hiperhidratação: a administração de grandes quantidades de fluídos, seja oral ou venosa, tem sido proposta e usada na prevenção e tratamento da CPPD. O mecanismo de ação deste tratamento seria o aumento da produção de líquor. No entanto, sua produção é um processo ativo que independe da ingestão de líquidos a exceção de pacientes gravemente desidratados. Não existem evidências de que seu uso possa produzir alívio da CPPD 7,37 .

- Cafeína: é uma das drogas mais comumente usadas no tratamento da CPPD. Sua recomendação fundamenta-se nas suas propriedades vasoconstritoras ${ }^{37,43}$;

- Injeção peridural com solução fisiológica: é proposto que a injeção e infusão de solução fisiológica peridural diminui o gradiente de pressão transdural e, assim, reduz o vazamento de líquor. $O$ alívio da cefaléia é rápido, porém pouco duradouro. Seu uso profilático tem resultados contraditórios ${ }^{36}$; 
- Cola de fibrina: baseados na proposição de que a perda persistente de líquor através do orifício formado pela agulha na duramáter é o mecanismo gerador da CPPD, alguns autores sugeriram o uso desta cola biológica para seu tratamento. A cola de fibrina já é utilizada com freqüência para o reparo da duramáter e prevenção de fistula liquórica após neurocirurgias. Estes autores relatam várias possíveis vantagens de seu uso profilático ou terapêutico ${ }^{44-46}$;

- Dextran peridural: o uso de dextran 40 foi utilizado com sucesso no tratamento da CPPD e sem complicações em 56 pacientes ${ }^{47}$. Foi sugerido como uma alternativa em pacientes HIV positivos ou testemunhas de Jeová ${ }^{7}$.

Para o paciente em questão, várias eram as opções anestésicas. Na primeira oportunidade optou-se pela realização de raquianestesia que resultou em CPPD. Uma das opções era a realização de uma nova raquianestesia, desta vez com uma agulha de calibre mais fino e/ou com bisel ponta de lápis. As agulhas de calibre mais fino e com bisel em ponta de lápis estão associadas a uma incidência menor de CPPD 6,11-14. Outra opção era a realização de anestesia geral. A grande vantagem desta técnica é a ausência de CPPD. No entanto, as desvantagens existem, como menor analgesia pós-operatória e maior custo. Outra técnica livre de CPPD, mas por sua vez com boa analgesia pós-operatória, é anestesia local associada à sedação. A técnica anestésica escoIhida foi a anestesia peridural, que não afasta a CPPD, pela possibilidade de punção acidental da duramáter, ocorrendo em até $6 \%$ dos casos ${ }^{15,16}$. Quando isto ocorre, a incidência de CPPD é alta ${ }^{17}$.

Foi exatamente o que ocorreu: houve perfuração acidental da duramáter. Diante desta situação, poder-se-ia realizar uma raquianestesia ou, como foi feito, nova punção peridural. Esta nova punção peridural foi feita um espaço acima do local anterior e foi introduzido o cateter peridural. A introdução do cateter visou a utilização de doses fracionadas de anestésico, procurando assim evitar a passagem acentuada de anestésico do espaço peridural para o subaracnóideo, que eventualmente poderia ocorrer, se fosse utilizado grande volume em bolus. Além disso, é descrito que a realização de anestesia peridural após a punção acidental da duramáter está relacionada à menor incidência de CPPD ${ }^{17}$.

Após o término da cirurgia e da anestesia, o anestesiologista responsável pelo caso julgou alta a chance de o paciente desenvolver CPPD (paciente jovem, passado de CPPD e perfuração da duramáter com agulha de grosso calibre).

A profilaxia da CPPD pode ser feita de várias maneiras. As mais freqüentes são a hiperhidratação, analgésicos, antiinflamatórios, cafeína e repouso. Todas com resultados inconstantes. A terapia mais eficaz da CPPD é o tampão sangüíneo peridural, ao passo que, seu uso profilático é recomendado por alguns e não aceito por outros. Lowenwirt e col. compararam o uso do tampão sangüíneo peridural profilático pós punção acidental de duramáter (pelo menos 5 horas após a injeção do anestésico local) com hiperhidratação venosa, repouso, teofilina e cafeína. Dos 24 pacientes do grupo que não receberam tampão sangüíneo peridural profilático, todos evoluíram com CPPD, enquanto no grupo que recebeu de 15 a $20 \mathrm{ml}$ de sangue autólogo peridural somente 4 desenvolveram CPPD, uma taxa de sucesso de $83 \%$. Os autores concluiram que o tampão sangüíneo peridural é uma técnica simples, segura e associada a um bom índice de sucesso ${ }^{48}$. Quaynor relatou $100 \%$ de sucesso em uma série de 10 pacientes nos quais o tampão sangüíneo peridural profilático foi feito dentro de até 15 minutos após a perfuração acidental ${ }^{49}$. O mesmo resultado ( $100 \%$ de sucesso) com uso do tampão sangüíneo peridural profilático imediato foi relatado por Ackerman ${ }^{50}$. Outro bom resultado foi obtido por Cheek, $90 \%$ de sucesso com o tampão sangüíneo peridural profilático feito pelo cateter ${ }^{51}$. Alguns autores não obtiveram boas taxas de sucesso como estas. Loeser obteve $71 \%$ e Palahniuk $54 \%$ de falha após o tampão sangüíneo peridural profilático imediato. Ambos os autores usaram $10 \mathrm{ml}$ ou menos, e este baixo volume foi considerado, por seus críticos, como responsável pela alta incidência de falhas ${ }^{29,52}$. Uma investigação sobre qual a melhor estratégia após punção inadvertida da duramáter revelou que $37 \%$ dos centros nos EUAe Canadá indicam o tampão sangüíneo peridural profilático imediato, enquanto que $8,6 \%$ dos centros do Reino Unido o fazem 15,53

A profilaxia com o tampão sangüíneo peridural, apesar de não uniformemente aceita, poderia ser uma boa estratégia. No entanto, o uso do tampão sangüíneo peridural em um determinado grupo de pacientes (pacientes HIV positivo, portadores de leucemias) é motivo de discussão ${ }^{54}$. A preocupação gira em torno da possibilidade de se expor o líquor à sangue contaminado. Já foi relatada uma série de pacientes HIV positivos que receberam tampão peridural com sangue autólogo, sem que houvesse deterioração neurológica ou qualquer outro tipo de prejuízo aos pacientes ${ }^{55-57}$. Ainda assim, alguns autores advogam cautela com esta técnica nestes pacientes ${ }^{58}$.

Uma alternativa ao tampão sangüíneo peridural é o tampão peridural com soluções colóides. Foi exatamente esta a estratégia adotada no caso em questão. Alguns relatos e duas séries (56 e 17 pacientes) mostraram sucesso com esta abordagem. Foram utilizados de 20 a $30 \mathrm{ml}$ de dextran 40 ${ }^{54,59}$. Assim como a infusão peridural de solução fisiológica, a injeção de colóides aumenta imediatamente a pressão peridural e com isso promove alívio rápido da cefaléia. Por causa de sua alta viscosidade a reabsorção dos colóides é lenta propiciando tempo para que o orifício da duramáter se feche. No entanto, o dextran 40 não obstrui o orifício como o sangüíneo faz através da coagulação. Pelo contrário, este colóide, como outros, tem propriedades anticoagulantes, o que faria supor um índice maior de recidiva tardia. Até o momento não foram relatados efeitos neurotóxicos desta solução, já o tampão sangüíneo peridural parece promover reação inflamatória moderada ${ }^{59}$. Disestesia temporária foi descrita em um dos relatos. Uma pesquisa realizada na França revelou que $11,6 \%$ dos 267 centros entrevistados usam ou já usaram tampão peridural com colóides. A solução mais usada naquele país é a gelatina ${ }^{60}$. Por outro lado, estudo semelhante Vol. 52, N 6, Novembro - Dezembro, 2002 
realizado no Reino Unido e Estados Unidos da América revelou que esta pratica é usada muito raramente, sendo o uso de infusão de solução fisiológica bastante freqüente ${ }^{53}$. Reynvoet e col. utilizaram com sucesso tampão peridural com dextran 40 em dois pacientes nos quais o tratamento com tampão sangüíneo peridural falhou ${ }^{61}$.

No presente caso, o paciente evoluiu assintomático, sem o surgimento de CPPD. No entanto, não se pode afirmar que isso se deveu ao uso de dextran 40 . O uso de soluções colóides como o dextran 40 deve ser melhor estudado e considerado como uma alternativa ao tampão sangüíneo peridural, principalmente naqueles casos em que este está contra-indicado.

\section{Epidural Patch with Dextran 40 to Prevent Postdural Puncture Headache in an HIV Pa- tient. Case Report}

Marcos Guilherme Cunha Cruvinel, TSA, M.D., Paulo Roberto Vieira Barbosa, M.D., Vera Coelho Teixeira, TSA, M.D., Carlos Henrique Viana de Castro, TSA, M.D.

\section{INTRODUCTION}

Postdural puncture headache (PDPH) may manifest after diagnostic and/or therapeutic lumbar puncture, spinal anesthesia or accidental dural puncture during epidural anesthe$\mathrm{sia}^{1,2}$. It is typically worsened by standing up and relieved in the horizontal position. These symptoms are caused by CSF leakage leading to decreased CSF pressure and/or volumes, causing intracranial structures displacement and traction ${ }^{3,4}$. Cerebral-vascular events may also worsen pain ${ }^{5,6}$. The diagnosis is essentially clinic. In general, PDPH starts 24 to 48 hours after puncture and evolves for spontaneous resolution within a few days; in some cases, however, it may be handicapping and last for months ${ }^{3,7,8}$.

The incidence of PDPH varies according to the population being investigated. Major predisposing factor is needle size. The reported incidence for $22 \mathrm{G}$ Quincke needles is $15.6 \%$, while for $29 \mathrm{G}$ Quincke needles it is $1.4 \%{ }^{9,10}$. Other factors may influence, such as needle point and bevel orientation ${ }^{11-13}$. Major patient-related factor is age (youngsters are more susceptible) ${ }^{11}$. Technical puncture difficulty, with the need for multiple punctures is considered a predisposing factor ${ }^{14}$.

The incidence of accidental dural puncture during epidural puncture attempts varies from $0.4 \%$ to $6 \%{ }^{15,16}$. In those cases, PDPH is high with reports of up to $86 \%{ }^{17}$. This report aimed at describing a case of epidural dextran 40 patch to prevent PDPH in an HIV-positive patient with a history of headache after previous spinal anesthesia.

\section{CASE REPORT}

Male HIV-positive patient, 31 years, $70 \mathrm{~kg}$, physical status ASA II, admitted for recurrent anal condylomatosis treatment. He reported severe and limiting headache for 2 weeks after the first surgery, performed under spinal anesthesia (25G Quincke needle). Treatment consisted of anti-inflammatory drugs, analgesics, caffeine, hydration and bed rest. For the second surgery, we decided for epidural anesthesia with $18 G$ Tuohy needle at $L_{3}-L_{4}$ using the loss of resistance to air technique. There has been an accidental dural puncture and a new puncture with the same technique at $L_{2}-L_{3}$ was successfully performed and followed by epidural catheter insertion. $2 \%$ lidocaine with epinephrine was administered in incremental doses of $40 \mathrm{mg}$, until a total of $120 \mathrm{mg}$. Surgery was performed without intercurrences and 150 minutes after anesthetic administration there was no motor or sensory block. After patient's consent, $20 \mathrm{ml}$ of $10 \%$ dextran 40 were administered via catheter. Patient evolved asymptomatic. Twenty-four hours after anesthesia, $20 \mathrm{ml}$ of $10 \%$ dextran 40 were injected and the epidural catheter was removed. Patient was discharged the day following the surgery and remained without headache complaints. During the first 24 hours after accidental dural puncture, oral anti-inflammatory drug (100 mg diclofenac), dipirone $(2.4 \mathrm{~g})$, caffeine (240 mg) and intravenous lactated Ringer's solution $(2400 \mathrm{ml})$ were administered.

\section{DISCUSSION}

Several approaches have been proposed to treat PDPH; blood patch, however, is currently accepted as the most effective ${ }^{18-20}$. Epidural autologous blood injection was initially suggested by Gormley ${ }^{21}$, in 1960, and was definitely introduced in the practice by Di Giovanni and Dunbar ${ }^{22}$, in 1970. There are two theories to explain the efficacy of epidural blood patch to treat PDPH. One suggests that epidural blood injection creates a clot which tamponades the dural hole and prevents additional CSF loss ${ }^{23-25}$. The other states that the blood volume injected in the epidural space increases CSF pressure and decreases cerebral and meningeal traction leading to symptoms relief ${ }^{26,27}$. Both theories are right ${ }^{28}$. The former explains the long-term efficacy of epidural blood patch and the latter the fast symptoms relief. The optimal moment for its administration is controversial. Some suggest the administration after some days of persistent PDPH ${ }^{29}$, others recommend its early administration ${ }^{30,31}$ while others indicate it as a prophylactic measure ${ }^{32,33}$. The optimal volume is also controversial and varies from 10 to $20 \mathrm{ml}^{34}$.

Among other treatment, some are worth mentioning:

- Bed rest: promotes headache relief and comfort, being a therapeutic approach ${ }^{7}$. It is not effective in prevention, although it may delay the appearance of symptoms ${ }^{7}$;

- Adrenocorticotrophic Hormone (ACTH): Kshatri and Foster have administered ACTH (1.5 units per kg in 1 to 2 liters of lactated Ringer's solution) in 20 patients with a 
$70 \%$ success rate ${ }^{35}$. Collier has also described the successful use of ACTH analogue to treat PDPH ${ }^{36}$. There is no apparent pharmacological mechanism for its efficacy 37.

- Sumatriptane: is used to treat migraine for causing cerebral vasoconstriction. Its efficacy in treating PDPH has been reported by several authors and its major advantage is to be non-invasive ${ }^{38-41}$. Its logic is based on the reflex cerebral vasodilation as a pathophysiological component of PDPH ${ }^{42}$. However, it is not free from adverse effects and cardiovascular complications have been reported ${ }^{37}$;

- Hyperhydration: the administration of large oral or intravenous amounts of fluids has been proposed and used to prevent and treat PDPH. The action mechanism of this treatment would be the increase in CSF production. However, its production is an active process not dependent on fluid ingestion, except for severely dehydrated patients. There are no evidences of its efficacy in relieving $\mathrm{PDPH}^{7,37}$;

- Caffeine: it is one of the most widely used drugs for PDPH. Its vasoconstrictor properties are the basis for its recommendation ${ }^{37,43}$;

- Epidural saline injection: it is proposed that epidural saline injection and infusion decreases transdural pressure gradient, thus decreasing CSF leakage. Headache relief is fast but short lasting. Its prophylactic use has contradictory results ${ }^{36}$;

- Fibrin glue: based on the proposition that persistent CSF loss through the dural hole created by the needle is the triggering PDPH factor, some authors have suggested the use of this biological glue for its treatment. Fibrin glue is already used after neurosurgeries. These authors report several potential advantages of its prophylactic or therapeutic use ${ }^{44-46}$;

- Epidural dextran: dextran 40 has been successfully used to treat PDPH without complications in 56 patients ${ }^{47}$. It is being suggested as an alternative for HIV-positive or Jehovah's Witnesses patients ${ }^{7}$.

Several were the anesthetic options for our patient. Spinal anesthesia was the first option and resulted in PDPH. Another option was a new spinal anesthesia, now with a thinner and/or pencil point needle. Thinner pencil point needles are associated to a lower incidence of PDPH ${ }^{6,11-14}$. General anesthesia was another option with the major advantage of not causing PDPH. However, there are disadvantages, such as less postoperative analgesia and higher cost. Another $\mathrm{PDPH}$-free technique, but with good postoperative analgesia is local anesthesia associated to sedation. Our technique of choice was epidural anesthesia, which does not rule out PDPH due to the possibility of accidental dural puncture, with an incidence of up to $6 \%{ }^{15,16}$. In this case, there is a high PDPH incidence ${ }^{17}$.

This was exactly what has happened: there has been an accidental dural perforation. Faced with this situation, spinal anesthesia could be attempted, or, as it has been the case, a new epidural puncture. This new epidural puncture was per- formed above the previous site and an epidural catheter was introduced aiming at fractionated anesthetic doses thus trying to avoid a marked passage of the anesthetic from the epidural space to the spinal space, which could occur if a large volume bolus was used. In addition, it has been described that epidural anesthesia after accidental dural puncture is related to less PDPH ${ }^{17}$.

At surgery and anesthesia completion, the anesthesiologist in charge considered a high chance of the patient developing PDPH (young patient, PDPH and dural puncture history) PDPH may be prevented in several ways. Most frequent approaches are hyperhydration, analgesics, anti-inflammatory drugs, caffeine and bed rest, all with inconstant results. Most effective PDPH therapy is epidural blood patch, but its prophylactic use is recommended by some and not accepted by others. Lowenwrit et al. have compared the use of prophylactic epidural blood patch after accidental dural puncture (at least 5 hours after local anesthetic injection) to intravenous hyperhydration, bed rest, theophylline and caffeine. From the 24 patients not receiving prophylactic blood patch, all have evolved with PDPH, while in the group receiving 15 to 20 $\mathrm{ml}$ of epidural autologous blood only 4 developed PDPH, with an $83 \%$ success rate. The authors have concluded that epidural blood patch is a simple and safe technique associated to a good success rate ${ }^{48}$. Quaynor has reported $100 \%$ success in a series of 10 patients in whom prophylactic blood patch was injected within 15 minutes after accidental perforation ${ }^{49}$. The same result ( $100 \%$ success) with immediate prophylactic blood patch was reported by Ackerman ${ }^{50}$. Another good result was achieved by Cheek: $90 \%$ success with epidural blood patch injected through the catheter ${ }^{51}$. Some authors have not achieved as good success rates. Loeser has obtained $71 \%$ and Palahniuk $54 \%$ of failure after immediate prophylactic blood patch. Both authors used $10 \mathrm{ml}$ or less and this low volume was considered by their critics as responsible for the high incidence of failures ${ }^{29,52}$. An investigation about the best strategy after inadvertent dural puncture has shown that $37 \%$ of USA and Canadian centers indicate immediate prophylactic blood patch, while $8.6 \%$ of UK centers recommend it ${ }^{15,53}$.

Prophylactic blood patch, although not uniformly accepted, could be a good strategy. However, the use of epidural blood patch in a certain group of patients (HIV-positive or leukemia patients) is a reason for discussion ${ }^{54}$. The concern is the possibility of exposing CSF to already contaminated blood. It has been reported a series of HIV-positive patients receiving autologous blood patch without neurological deterioration or any other type of damage to patients ${ }^{55-57}$. Still, some authors advocate care with this technique in such patients ${ }^{58}$.

An alternative to the epidural blood patch is the epidural patch with colloid solutions. This was exactly the strategy adopted in our case. Some reports and two series ( 56 and 17 patients) have shown the success of this approach with 20 to $30 \mathrm{ml}$ of dextran $40^{54,59}$. Similar to the epidural saline injection, colloid injection promptly increases epidural pressure thus promoting a fast headache relief. Due to its high viscosity, colloids absorption is slow giving time for the dural hole to 
heal. However, dextran 40 does not block the hole as blood does through coagulation. Conversely, this colloid, as others, has anticoagulant properties, which would lead to the assumption of a higher late recurrence rate. There are no reports to date about neurotoxic effects of this solution, but the epidural blood patch seems to promote moderate inflammatory reactions ${ }^{59}$. Temporary disesthesia has been reported. A French research has shown that $11.6 \%$ of 267 centers investigated use or have already used epidural patch with colloids. Most popular solution in that country is gelatin ${ }^{60}$. On the other hand, a similar study conducted in the United Kingdom and in the United States has shown that this practice is very seldom used being very frequent the use of saline infusion ${ }^{53}$. Reynvoet et al. have successfully used epidural dextran 40 patch in two patients who failed to respond to epidural blood patch ${ }^{61}$.

In our case, the patient evolved without symptoms and $\mathrm{PDPH}$. However, it cannot be stated that this was due to dextran 40 . The use of colloid solutions, such as dextran 40 , should be further investigated and be considered an alternative to epidural blood patch, especially when the latter is counterindicated.

\section{REFERÊNCIAS - REFERENCES}

01. Stephen L - Postdural puncture: implications and complications. Current Opinion in Anesthesiology, 1999;12:271-275.

02. Halpern S, Preston R - Postdural puncture headache and spinal needle design: metaanalyses. Anesthesiology, 1994;81: 1376-1383.

03. Gielen M - Postdural puncture headache (PDPH): a review. Reg Anesth, 1989;14:101-106.

04. Grant R, Condon B, Hart l et al - Changes in intracranial CSF volume after lumbar puncture and their relationship to post-LP headache. J Neurol Neurosurg Psychiatr, 1991;54:440-442.

05. Kongstad L, Grande PO - Local vascular response during organ elevation: a model for cerebral effects of upright position and dural puncture. Acta Anaesthesiol Scand, 1999;43:438-446.

06. Hattingh J, McCalden JA - Cerebrovascular effect of cerebral fluid removal. S Afr Med J, 1978;54:780-781.

07. Imbelloni LE, Carneiro ANG - Cefaléia pós-raquianestesia: causas, prevenção e tratamento. Rev Bras Anestesiol, 1997; 47:453-464.

08. Weir EC - The sharp end of the dural puncture. BMJ, 2000;320: 127.

09. Perterman SB - Postmyelography headache rates with Whitacre versus Quincke 22-gauge spinal needles. Radiology, 1996;200: 771-778.

10. Dittman M, Renkle F - Spinal anaesthesia with extremely fine needles. Anesthesiology, 1989;70:1035-1036.

11. Lybecker H, Moller JT, May O et al - Incidence and prediction of postdural puncture headache. A prospective study of $1021 \mathrm{spi}-$ nal anesthesia's. Anesth Analg, 1990;70:389-394.

12. Shutt LE, Valentine SJ, Wee MY et al - Spinal anaesthesia for caesarean section: comparison of $22 \mathrm{G}$ and $25 \mathrm{G}$ Whitacre needles with 26G Quincke needles. Br J Anaesth, 1992;69: 589-594.

13. Flaatten $\mathrm{H}$, Thorsen $\mathrm{T}$, Askeland $\mathrm{B}$ et al - Puncture technique and postdural puncture headache. A randomized, double-blind study comparing transverse and parallel puncture. Acta Anaesthesiol Scand, 1998;42:1209-1214.
14. Seeberger MD, Kaufman M, Staender S et al - Repeated dural puncture increases the incidence of postdural puncture headache. Anesth Analg, 1996;82:302-305.

15. Berger CW, Crosby ET, Groecki W - North American survey of the management of dural puncture occurring during labor epidural analgesia. Can J Anaesth, 1998;45:110-114.

16. Lambert DH, Hurley RJ, Hertwing L et al - Role of needle gauge and tip configuration in the production of lumbar puncture headache. Anesthesiology, 1997;22:66-72.

17. Costigan SN, Spigge JS - Dural puncture: the patients perspective. A patient survey of cases at a DGH maternity unit 1983-1993. Acta Anaesthesiol Scand, 1996;40:710-714.

18. Seebacher J, Ribeiro V, LeGuillou JL et al - Epidural blood patch in the treatment of post dural puncture headache: a double blind study. Headache, 1989;29:630-632.

19. Vercauteren MP, Hoffmann VH, Mertens E et al - Seven-year review of requests for epidural blood patch for headache after dural puncture: referral patterns and the effectiveness of blood patches. Eur J Anesthesiol, 1999;16:298-303.

20. Pedrosa GC, Jardim JL, Palmeira MA - Tampão sangüíneo peridural e alta hospitalar precoce: análise de 60 pacientes portadores de cefaléia pós-raquianestesia. Rev Bras Anestesiol, 1996;46:8-12.

21. Gormley JB - Treatment of postspinal headache. Anesthesiology, 1960;21:565-566.

22. DiGiovanni AJ, Dunbar BS - Epidural injections of autologus blood for postlumbar puncture headache. Anesth Analg, 1970;49:268-271.

23. Vakharia SB, Thomas PS, Rosenbaum AE et al - Magnetic resonance imaging of cerebrospinal fluid leak and tamponade effect of blood patch in postdural puncture headache. Anesth Analg, 1997;84:585-590.

24. Djurhuus H, Rasmussen M, Jensen EH - Epidural blood patch illustrated by CT-epidurography. Acta Anaesthesiol Scand, 1995;39:613-617.

25. Cook MA, Watkins-Pitchford JM - Epidural blood patch: a rapid coagulation response. Anesth Analg, 1990;70:567-568.

26. Colonna-Romano P, Linton $P$ - Cervical dural puncture and lumbar extradural blood patch. Can J Anaesth, 1995;42:1143-1144.

27. Griffiths AG, Beards SC, Jackson A et al - Visualization of extradural blood patch for post lumbar puncture headache by magnetic resonance imaging. Br J Anaesth, 1993;70:223-225.

28. Safa-Tisseront V, Thormann F, Malassiné $P$ et al - Effectiveness of epidural blood patch in the management of post-dural puncture headache. Anesthesiology, 2001;95:334-339.

29. Loeser EA, Hill GE, Bennett GM et al - Time vs success rate for epidural blood patch. Anesthesiology, 1978;49:147-148.

30. Quaynor H, Corbey M - Extradural blood-patch: why delay? Br J Anaesth, 1985;57:538-540.

31. Christensen FR, Lund J - Accidental dural puncture: immediate or delayed blood patch. Br J Anaesth, 1983;55:89-90.

32. Colonna-Romano P, Shapiro BE - Unintentional dural puncture and prophylactic epidural blood patch in obstetrics. Anesth Analg, 1989;69:522-523.

33. Cheek TG, Banner R, Sauter J et al - Prophylactic extradural blood patch is effective: a preliminary communication. $\mathrm{Br} \mathrm{J}$ Anaesth, 1988;61:340-342.

34. Szeinfeld M, Ihmeidan IH, Moser MM et al - Epidural blood patch: evaluation of the volume and spread of blood injected into the epidural space. Anesthesiology, 1986;64:820-822.

35. Kshatri AM, Foster PA - Adrenocorticotropic hormone infusion as a novel treatment for postdural puncture headache. Reg Anesth, 1997;22:432-434.

36. Collier BB - Treatment for postdural puncture headache. Br J Anaesth, 1994;72:366-367. 
37. Longo S - Postdural puncture: implications and complications. Current Opinion in Anesthesiology, 1999;12:271-275.

38. Carp H, Singh PJ, Vadhera R et al - Effects of serotonin-recepter agonist sumatriptan on postdural headache: report of six cases. Anesth Analg, 1994;79:180-182.

39. Hutter CD - Sumatriptan and postdural puncture headache. Anaesthesia, 1997;52:1119-1120.

40. Connelly NR, Parker RK, Rahimi ADO et al - Sumatriptan in patients with post dural puncture headache. Anesthesiology, 1999;90 (4AS)Suppl:31A.

41. Sprigge JS - The use of sumatriptan in the treatment of postdural puncture headache after accidental lumbar puncture complicated a blood patch procedure. Anaesthesia, 1999;54:95-96.

42. Hodgson C, Roitberg-Henry A - The use of sumatriptan in the treatment of postdural puncture headache. Anaesthesia, 1997;52:808-809.

43. Camann WR, Murray RS, Mushlin PS et al - Effects of oral caffeine on postdural puncture headache: a double-blind, placebo-controlled trial. Anesth Analg, 1990;70:181-184.

44. Gil F, Garcia-Aguardo R, Barcia J et al - The effect of fibrin glue patch in an in vitro model of postdural puncture leakage. Anesth Analg, 1998;87:1125-1128.

45. Crul BJP, Gerritse B, van Dongen RT et al - Epidural fibrin glue injection stops persistent postdural puncture headache. Anesthesiology, 1999;91:576-577.

46. García-Aguado R, Gil F, Barcia JA et al - Prophylactic percutaneous sealing of lumbar postdural puncture hole with fibrin glue to prevent cerebrospinal fluid leakage in swine. Anesth Analg, 2000;90:894-998.

47. Barrios-Alarcon J, Aldrete JA, Paragas TD - Relief of postlumbar puncture headache with epidural dextran 40: a preliminary report. Reg Anesth, 1989;14:78-80

48. Lowenwirt I, Cohen S, Zephyr J et al - Can prophylactic epidural patch reduce the incidence and severity of postpartum dural puncture headache in obstetrics? Anesth Analg, 1998;86(2S): 378 S.

49. Quaynor H, Corbey M - Extradural blood patch. Br J Anaesth, 1986;58:468-469.

50. Ackerman WE, Colclough GW - Prophylactic epidural blood patch: the controversy continues. Anesth Analg, 1987;66: 913-914.

51. Cheek TG, Banner R, Gutsche BB - Prophylactic extradural blood patch is effective. Br J Anaesth, 1988;61:340-342.

52. Palahniuk RJ, Cumming M - Prophylactic blood patch does not prevent post lumbar puncture headache. Can Anesthetist Soc, 1997;26:132-133

53. Sajjad T - Current management of inadvertent dural taps occurring during the siting of the epidurals for pain relief in labor: a survey of maternity in the United Kingdom. Anaesthesia, 1995;50: 156-161.

54. Cicarelli DD, Stábile Jr SL, Guimarães CM et al - Cefaléia pós-punção da duramáter em paciente HIV positivo. Qual o melhor tratamento? Rev Bras Anestesiol, 2000;50:306-308.

55. Tom DJ, Gulevich SJ, Shapiro HM et al - Epidural blood patch in the HIV-positive patient: review of clinical experience. Anesthesiology, 1992;76:943-947.
56. Frame WA, Lichtmann MW - Blood patch in the HIV-positive patient. Anesthesiology, 1990;73:1297-1298.

57. Parris WC - Postdural puncture headache and epidural blood patch in an AIDS patient. J Clin Anesth, 1997;9:87-88.

58. Miguel R, Behrmann H, Diaz A - Postdural puncture headaches in special patient populations. Anesth Analg, 1999;89:264-265.

59. Souron V, Hamza J - Treatment of postdural puncture headache with colloid solutions: an alternative to epidural blood patch. Anesth Analg, 1999;89:1333-1334.

60 . Souron V, Simon L, Sacquin P et al - Current management of inadvertent dural taps occurring during epidural analgesia for pain relief in labor: a French postal survey. Br J Anaesth, 1998;80: A523.

61. Reynvoet MEJ, Cosaert PAJM, Desmet MFR et al - Epidural dextran 40 patch for postdural puncture headache. Anaesthesia, 1997;52:886-888.

\section{RESUMEN}

Cruvinel MGC, Barbosa PRV, Teixeira VC, Castro CHV - Tampón Peridural con Dextran 40 en la Profilaxia de la Cefalea Pós-Punción Accidental de la Duramáter en Paciente SIDA Positivo. Relato de Caso

Justificativa y Objetivos - La cefalea pós-punción de duramáter es una complicación bien conocida de las anestesias subaracnóideas y peridurales, siendo el tampón sanguíneo considerado el tratamiento más eficaz hasta el momento. Este es un procedimiento invasivo y sujeto a complicaciones graves. Su uso en ciertos pacientes, como portadores de SIDA o leucemias, es motivo de debate. Varias alternativas han sido relatadas. El objetivo de este articulo es presentar un caso del uso del tampón peridural con dextran 40 en la profilaxia de la cefalea pós-punción de duramáter en paciente portador del virus de la imunodeficiencia humana (HIV), con historia de cefalea en anestesia subaracnóidea anterior.

Relato de Caso - Paciente masculino, 31 años, 70 kg, estado físico ASA II, portador de SIDA, para tratamiento de condilomatosis anal recidivada, con relato de cefalea intensa y limitante durante dos semanas después de anestesia subaracnóidea (aguja Quincke 25G). Durante la tentativa de anestesia peridural con aguja de Tuohy $18 G$ en $L_{3}-L_{4}$, hubo perforación accidental de la duramáter. Fueron inyectados, por dos veces, $20 \mathrm{ml}$ de dextran 40 a $10 \%$ por catéter peridural; la primera, 150 minutos después de la administración de los anestésicos y la segunda en la mañana siguiente a la cirugía. El paciente evoluyó asintomático y recibió alta al día siguiente a su internación.

Conclusiones - El uso del tampón con soluciones coloides como el dextran 40 no está bien establecido, sin embargo existen algunos relatos de su uso con suceso y entendemos que su potencial debe ser mejor explorado. 